\title{
THE ROLE OF NATIONAL CULTURE IN THE RELATIONSHIP BETWEEN SUSTAINABILITY PRACTICES AND SUSTAINABILITY PERFORMANCE
}

CRISTINA SANCHA (corresponding author)

Department of Operations, Innovation, and Data Sciences

ESADE Business School, Ramon Llull University, Barcelona, Spain

cristina.sancha@esade.edu

\section{ANNACHIARA LONGONI}

Department of Operations, Innovation, and Data Sciences

ESADE Business School, Ramon Llull University, Barcelona, Spain

annachiara.longoni@esade.edu

\section{CRISTINA GIMÉNEZ}

Department of Operations, Innovation, and Data Sciences

ESADE Business School, Ramon Llull University, Barcelona, Spain

cristina.gimenez@esade.edu

\begin{abstract}
This paper aims to examine the role of national culture in the relationship between sustainability practices (social and environmental practices) and sustainability performance (social and environmental performance). While previous literature has focused on the influence of national culture on the decision-making and ethical behaviors of managers, the role of national culture on the effectiveness of sustainability practices has been rather neglected. Our study addresses this gap by highlighting the relevance of national culture as a contextual element when implementing sustainability practices in different countries. Based on a multilevel regression analysis using data from 484 firms in nine countries (China, Germany, Hungary, India, Italy, Japan, Malaysia, Slovenia, and Sweden), we found that the impact of social practices on social performance is accentuated in countries characterized by high uncertainty avoidance and high masculinity. The impact of environmental practices on environmental performance, however, is not affected by national culture.
\end{abstract}

\section{KEYWORDS}

sustainability practices; environmental performance; social performance; Hofstede cultural dimensions; multilevel regression 


\section{INTRODUCTION}

In light of increases in sustainability concerns and growing globalization, firms are being called to understand the effects of implementing sustainability practices in a global context. Sustainability practices are defined as those practices and actions that make a company achieve business processes that lead to improved sustainability outcomes (Seuring \& Müller, 2008). Examples of these practices are energy, water consumption, and pollution reduction programs or the implementation of work/life balance policies (Longo, Mura, \& Bonoli, 2005; Sarkis, 1998). Sustainability performance is then operationalized through the concept of the triple bottom line and includes not only economic indicators as measures of firm performance but also environmental (e.g., reduction in pollution levels) and social (e.g., improvements in employees' health and safety) measures (Gimenez, Sierra, \& Rodon, 2012).

Although globalization usually leads to the standardization of policies and practices (Newman \& Nollen, 1996), the "one size fits all" view has often been contested. Contingency Theory proposes that organizational practices should fit the context in which they are implemented for these to be effective (Lawrence \& Lorsch, 1967; Drazin \& van de Ven, 1985). In that sense, Thanetsunthorn (2015) pointed out that firms should be sensitive toward national culture and define sustainability practices that are in line with the cultural values of the country in which they are implementing such. For instance, the implementation of sustainability practices that imply collaboration between partners might be more or less effective depending on certain cultural aspects such as a country's collectivistic-individualistic orientation.

The literature shows differences in the adoption of sustainability practices in different national culture environments (e.g., Wagner, 2009; Vachon, 2010; Caprar \& Neville, 2012; Thanetsunthorn, 2015; Luo, Tang, \& Peng, 2018). Countries that score high on power distance, for example, are more reluctant to implement sustainability practices since these countries exhibit higher levels of corruption and lower levels of human rights policies in corporations (Vachon, 2010). These results, however, do not investigate the effect of national culture as a contingency factor affecting the effectiveness of sustainability practices; that is, these papers have looked at the direct effect of national culture on the adoption of sustainability practices but not at how differences in national cultures might affect the effectiveness of these practices on sustainability performance. Indeed, as predicted by the Contingency Theory, which states that a firm's performance is dependent upon the fit between 
its processes, practices, and external factors (Lawrence \& Lorsch, 1967; Thompson, 1967), the effectiveness of a specific practice may vary according to the (national culture) context in which it is adopted (Wong, Sancha, \& Thomsen, 2017).

This paper attempts to fill this gap by adopting a contingency perspective on the sustainability practices-sustainability performance relationship and thus answer the following research question: What is the impact of national culture on the sustainability practices-performance relationship in different cultural environments? It adopts the lenses of the Contingency Theory and empirically tests the effectiveness of sustainability practices in countries characterized by different national cultures. As such, while previous literature has studied differences in the adoption of practices due to differences in national cultures, this paper will contribute to the understanding of the effectiveness of sustainability practices in a global context, that is, of what practices are more effective in specific national cultural contexts. We therefore aim to extend the knowledge we have about the relationship between national culture and sustainability by understanding in which national cultural contexts do specific sustainability practices lead to higher (lower) sustainability performance improvements.

The findings of this study, moreover, are relevant for managers as these will help them predict the effectiveness of their sustainability practices in their global units and identify areas where specific organizational practices can be implemented to counterbalance the negative impact of specific national cultural traits.

\section{LITERATURE REVIEW AND HYPOTHESIS DEVELOPMENT}

Sustainability is concerned with the impact present actions will have on the ecosystems, societies, and environments of the future (Elkington, 1994). Firms need to reflect such concerns in their strategic and operational planning by considering a set of responsibilities that focus on environmental and social dimensions. Sustainability as such consequently entails environmental and social practicesenvironmental practices include various elements such as pollution control or prevention (Klassen \& Whybark, 1999) while social practices deal with the health, safety, and satisfaction of employees (Longo et al., 2005). These practices involve evaluative and preventive measures (for example, EMAS/ISO 14000, SA 8000) and/ or work/life balance policies. 
Multinational companies are called to deploy sustainability practices in different countries and with different partners worldwide. In light of the Contingency Theory, however, the same practices may not have the same effectiveness everywhere, which may vary according to the context in which such practices are adopted. Rather than developing a standard and homogeneous approach, high levels of culturalspecificity will require different practices fitting to each local context while focusing on contingencies related to national culture. As suggested by Caprar and Neville (2012), certain sustainability principles are more compatible with certain national cultural dimensions than are others. For instance, those cultural contexts that include norms and values aligned with sustainability principles (e.g., countries that score high in the femininity dimension) present a higher likelihood of sustainability practices adoption.

Consistent with prior literature, we define national culture as "patterns, explicit and implicit, of and for behaviour acquired and transmitted by symbols, constituting the distinctive achievements of human groups" (Kroeber \& Kluckhohn, 1952: 13). In this study, moreover, we adopt Hofstede's national culture framework (1983) which comprises the following dimensions: power distance, individualism-collectivism, masculinity-femininity, and uncertainty avoidance. While this model has evolved to include two additional dimensions related to long-term vs. short-term orientation and indulgence, only the original four dimensions will be considered to avoid construct-validity related issues and following previous research on sustainability which did not include these two newly added dimensions (e.g., Vachon, 2010; Thanetsunthorn, 2015). This will ensure that results will be in line with previous conceptualizations of national culture.

It is important to mention that some authors have pointed out some critiques of Hofstede's model based on its lack of generalizability, the validity of its constructs, the date of the study, and the assumed homogeneity in each of the studied cultures (Magnusson, Wilson, Zdravkovic, Zhou, \& Westjohn, 2008; Sivakumar \& Nakata, 2001; Smith, 1992). Hofstede's cultural dimensions, however, have been adopted extensively in several studies and are widely accepted in the management literature (e.g., Cagliano, Caniato, Golini, Longoni, \& Micelotta, 2011; Pagell, Katz, \& Sheu, 2005; Power, Schoenherr, \& Samson, 2010; Vecchi \& Brennan, 2009; Wiengarten, Fynes, Pagell, \& Búrca, 2011). The construct validity and relevance of Hofstede's dimensions have also been reconfirmed (Merritt, 2000), and it has been shown that 
Hofstede's model compares satisfactorily with other existing models (e.g., GLOBE). Thus, while all national culture frameworks show strengths and weaknesses, we have chosen to use Hofstede's model not only because of its extensive use in previous literature but also in light of the objective of this study, which is to include the national culture perspective (and not defend the use of one specific framework).

The different sets of values, beliefs, ideas, attitudes, and morals that are ingrained in a national culture guide individuals on which behaviors are acceptable and unacceptable (Vitell, Nwachukwu, \& Barnes, 1993). Indeed, this is true not only for individuals but also for organizations (Hofstede, 1985). In an organizational context, the different characteristics of national cultural dimensions are reflected in managerial values, beliefs, and business mindsets (Peng \& Lin, 2009). Specific predictions regarding the impact of the different dimensions of national culture on the sustainability practices-performance relationship have thus been developed; these are discussed in the following paragraphs. While these dimensions are seen to moderate the relationship between practice and performance, they do not mediate between the two because such would imply that practices would lead to higher performance results only if that particular national culture dimension is present.

\section{Power Distance}

The power distance dimension of national culture refers to the degree to which less powerful members of a society accept that power is distributed unequally (Hofstede, 1980). In a context of high power distance, a questionable business practice tends to be accepted as ethical (Cohen, Pant, \& Sharp, 1996), and the following behaviors seem to be more present than they would be otherwise in low power distance contexts: managers showing less consideration for employees (Vachon, 2010) and individuals being less sensitive toward ethical acts and more tolerant of inequality (House, Hanges, Javidan, Dorfman, \& Gupta, 2004; Scholtens $\&$ Dam, 2007). High power distance societies, in addition, tend to manifest higher acceptance levels for poor working conditions and pollution (Husted, 2005; Park, Mezias, \& Song, 2004). Based on these characteristics, therefore, it can be expected that sustainability practices do not fit well with high power distance societies, thereby limiting the effectiveness of such efforts. Indeed, the recognition and remedy of social and environmental risks are more timely addressed in contexts characterized by low power distance (Ringov \& Zollo, 2007). This latter context might fit better 
with an effective implementation of sustainability practices, thereby leading to higher sustainability outcomes. As such, we hypothesize that

H1: The national culture dimension of power distance negatively moderates the relationship between a) environmental practices and environmental performance and b) social practices and social performance.

Individualism

Individualism is generally defined as the cultural belief that individuals should take responsibility primarily for their own interests and those of their immediate family (Hofstede, 1980; Triandis, 1995). In societies with high individualism, individuals tend to value personal time, freedom, and independence; they believe that personal interests are more important than the interests of others. Such individuals, in fact, are characterized by superficiality and avoid cooperative as well as sociallyoriented practices (Gray \& Massimino, 2014; Arellano, Sancha, Netland, \& Thomsen, 2020). Accordingly, individuals in highly individualistic societies demonstrate less concern about the broader impact of business on both society and the environment unless doing so is in their recognized self-interest (Thanetsunthorn, 2015). This context might not fit, therefore, with the implementation of sustainability practices, thereby limiting their effectiveness. Instead, one is more likely to find a strong focus on the well-being of the broader community and the environment as well as a feeling of responsibility to contribute by being a good corporate citizen in societies with a strong collectivist orientation (Moorman \& Blakely, 1995). Practices that include a social objective or component fit well in highly collectivistic environments (Arellano et al., 2020), making such contexts a more likely and better fit for the adoption of sustainability practices and thereby enhancing the effectiveness of such efforts. As such, we hypothesize that

H2: The national culture dimension of individualism negatively moderates the relationship between a) environmental practices and environmental performance and b) social practices and social performance.

\section{Masculinity}

Highly masculine societies place a low value on caring for others, inclusion, cooperation, and solidarity; conversely, career advancement, material success, 
and competition are considered paramount. Some of the most frequently cited reasons for unethical behaviors are related to the greed and competitiveness of masculine individuals (Vitell \& Festervand, 1987). Husted (2005), furthermore, found that masculinity was inversely related to social and institutional capacity for environmental sustainability. Given that masculine societies emphasize the need for competitiveness, success, individual achievements, and low cooperation (Tice \& Baumeister, 1985), we therefore suggest that a high masculinity context does not fit well with sustainability practices, thereby reducing their impact on sustainability performance according to the tenets of the Contingency Theory. Indeed, as opposed to masculine contexts, countries with high levels of femininity prioritize the conservation of the environment and adopt a service orientation (Katz, Swanson, \& Nelson, 2001). We thus posit that they favor an effective implementation of sustainability practices and therefore formulate the following hypothesis:

H3: The national culture dimension of masculinity negatively moderates the relationship between a) environmental practices and environmental performance and b) social practices and social performance.

\section{Uncertainty Avoidance}

Uncertainty avoidance indicates the extent to which individuals tolerate ambiguity in their lives and are willing to take risks. In high uncertainty avoidance societies, people tend to be more anxious (Hofstede, 2001). They create rules and regulations and set up institutions to ensure standardization and conformity that foster continuity (Katz et al., 2001). Individuals in low uncertainty avoidance societies, on the other hand, have a higher propensity for risk and are less likely to be reliant on written and explicit rules and regulations in dealing with unfamiliar situations (Hofstede, 2001). Based on the characteristics of high uncertainty avoidance societies, therefore, it can be expected that sustainability practices fit well with their context and are not in line with low uncertainty avoidance environments. We therefore hypothesize that

H4: The national culture dimension of uncertainty avoidance positively moderates the relationship between a) environmental practices and environmental performance and b) social practices and social performance. 


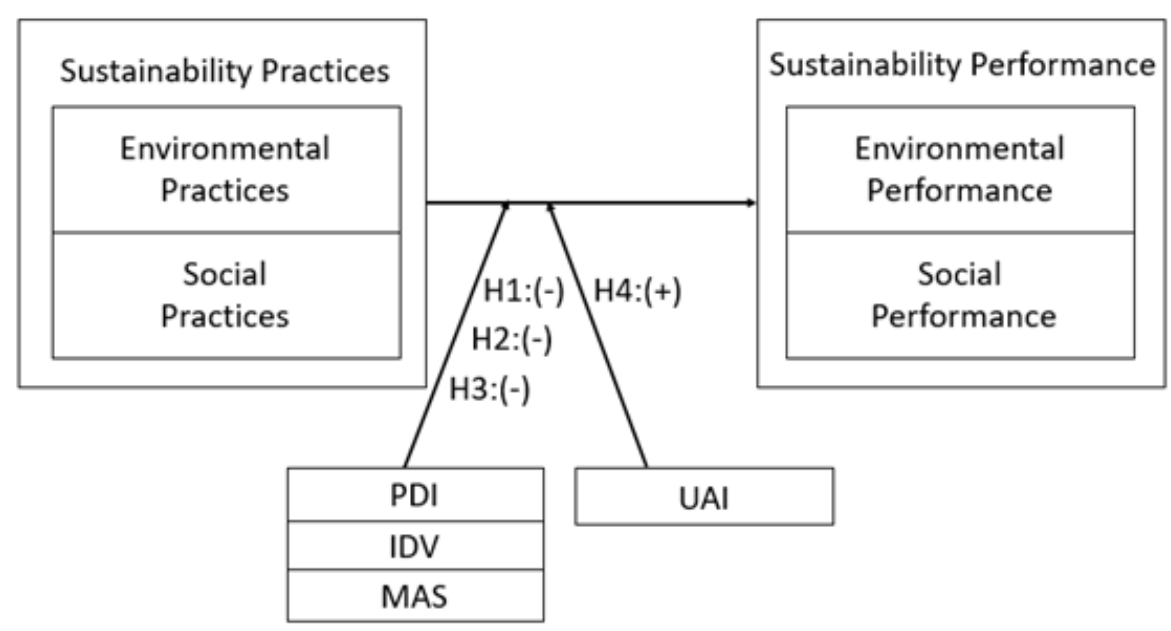

Figure 1: Research Framework

\section{METHODOLOGY}

\section{Data Collection}

To test our hypotheses, we combined primary and secondary data. Primary data was collected through the International Manufacturing Strategy Survey (IMSS, 2013). Launched in 1992 by the London Business School (U.K.) and the Chalmers University of Technology (Sweden), the IMSS studies manufacturing and supply chain strategies across countries. It comprises three different sections: the first includes items related to business units' competitive strategy and manufacturing plant organization, the second deals with the strategy and performance of the plant's main dominant activity, and the third describes current manufacturing and supply chain practices. The IMSS is a common survey instrument with a data collection protocol developed by researchers from different institutions, with the same questionnaire administered simultaneously in different countries by local research groups. The magnitude of the survey (i.e., its relatively high sample size), the involvement of companies in developing the questionnaire (ensuring content validity), and the history of the survey (both instrument and protocol have been extensively pre-tested) are the strengths of the IMSS data set (Wiengarten, Pagell, Ahmed, \& Gimenez, 2014). Local research coordinators in each country also perform non-response and late-response 
bias tests before sending the data to the central coordinator. For the purposes of this study, we used manufacturing plant level data on sustainability practices and sustainability performance from the second and third sections of the survey.

The initial sample of the original IMSS-VI consisted of 931 manufacturing plants from 22 countries. Given that the same questionnaire with the same items was distributed across countries, we computed the reliability scores of environmental and social practices as well as of environmental and social performance for each country. Following previous studies, we dropped those countries that had a Cronbach $\alpha$ lower than 0.70 (Singh, 1995; Parboteeah, Addae, \& Cullen, 2012). This measure was taken to ensure the consistency of construct reliability across different countries, and resulted in a final sample size of 484 plants from 9 countries. The descriptive statistics of the sample can be found in Table 1 .

\begin{tabular}{|c|c|c|c|c|c|c|c|c|}
\hline Country & $\mathrm{N}$ & $\%$ & $\begin{array}{c}\text { ISIC } \\
\text { Code }^{*}\end{array}$ & $\mathrm{~N}$ & $\%$ & Size & $\mathrm{N}$ & $\%$ \\
\hline China & 128 & 26 & 25 & 112 & 23 & Less than 50 & 15 & 3.10 \\
\hline Germany & 15 & 3 & 26 & 76 & 16 & Between 50 and 249 & 168 & 34.7 \\
\hline Hungary & 57 & 12 & 27 & 95 & 20 & Between 250 and 499 & 82 & 16.9 \\
\hline India & 91 & 19 & 28 & 112 & 23 & More than 500 & 218 & 45 \\
\hline Italy & 48 & 10 & 29 & 58 & 12 & Not defined & 1 & 0.2 \\
\hline Japan & 82 & 17 & 30 & 31 & 6 & Total & 484 & 100 \\
\hline Malaysia & 14 & 3 & Total & 484 & 100 & & & \\
\hline Slovenia & 17 & 4 & & & & & & \\
\hline Sweden & 32 & 7 & & & & & & \\
\hline Total & 484 & 100 & & & & & & \\
\hline
\end{tabular}

Table 1: Descriptive Statistics of the Sample

*ISIC Codes: 25-Manufacture of fabricated metal products, except machinery and equipment; 26-Manufacture of computer, electronic, and optical products; 27-Manufacture of electrical equipment; 28-Manufacture of machinery and equipment not elsewhere classified; 29-Manufacture of motor vehicles, trailers, and semi-trailers; 30-Manufacture of other transport equipment.

For the secondary data, we used Hofstede's (1983) national culture framework. Hofstede developed a quantitative model that allows for the measurement of differences between national cultures according to four cultural traits: power distance, individualism-collectivism, masculinity-femininity, and uncertainty avoidance (Hofstede, 1983). The most updated scores of this model (2010) were used in this study, making for a difference of three years between the national cultural values and 
the collected primary data (2013). Recent studies have shown, however, that there are cultural traits that remain stable even after 25 years (Matei \& Abrudan, 2018), thereby ensuring coherence between both sets of data.

The scale of each dimension runs from 0 to 100. A score lower than 50 for a certain dimension means that country scores LOW for that particular dimension while a score above 50 registers as HIGH. China's scores, for example, are 80 (power distance), 20 (individualism), 66 (masculinity), and 30 (uncertainty avoidance), meaning the country is characterized as having a national culture where power distance, masculinity orientation, and collectivism (as opposed to individualism) are high and where uncertainty avoidance is low. Table 2 shows the Hofstede scores for each country.

\begin{tabular}{|c|c|c|c|c|}
\hline Country & $\begin{array}{c}\text { Power } \\
\text { Distance }\end{array}$ & $\begin{array}{c}\text { Uncertainty } \\
\text { Avoidance }\end{array}$ & Individualism & Masculinity \\
\hline China & 80 & 30 & 20 & 66 \\
\hline Germany & 35 & 65 & 67 & 66 \\
\hline Hungary & 46 & 82 & 80 & 88 \\
\hline India & 77 & 40 & 48 & 56 \\
\hline Italy & 50 & 75 & 76 & 70 \\
\hline Japan & 54 & 92 & 46 & 95 \\
\hline Malaysia & 100 & 36 & 26 & 50 \\
\hline Slovenia & 71 & 88 & 27 & 19 \\
\hline Sweden & 31 & 29 & 71 & 5 \\
\hline Mean & 60.44 & 59.67 & 51.22 & 57.22 \\
\hline SD & 21.62 & 24.44 & 21.90 & 27.76 \\
\hline
\end{tabular}

Table 2: Hofstede's Cultural Dimension Scores per Country

\section{Measures}

In our analysis, we have two constructs related to practices (environmental practices and social practices) and two constructs related to performance (environmental performance and social performance). All items were developed based on previous literature. Environmental practices include programs related to managing energy and water consumption and pollution emission as well as waste recycling programs (Sarkis, 1998; Klassen \& Whybark, 1999). Social practices include items related to occupational health and safety management systems and work/life 
balance policies (Longo et al., 2005). Environmental performance considers items that measure the reduction in levels of energy consumption, pollution, emissions, and waste production (Zhu \& Sarkis, 2004) while social performance includes workers' motivation and satisfaction as well as health and safety conditions (Gimenez et al., 2012). Appendix A provides more details with respect to these constructs and items, and other studies using the IMSS database have measured environmental and social practices in a similar fashion (e.g., Golini, Longoni, \& Cagliano, 2014; Golini, de Marchi, Boffelli, \& Kalchschmidt, 2018).

In addition to these four main constructs, we also included some control variables in our model. We added firm size (measured as the natural logarithm of the number of employees) given that previous literature points out that larger firms are more inclined and have more resources to invest in green and sociallyoriented sustainability dimensions (Min \& Galle, 2001). We also considered the per capita gross national income (GNI) of a country using the purchasing power parity estimation of GNI (Parboteeah et al., 2012) to control for a country's wealth as previous research has connected country wealth to sustainability (Husted, 2005). This country-level variable was collected from the World Bank economy and growth indicators database (World Bank, n.d.).

\section{Assessment of Validity and Reliability}

The adequacy of the scales was evaluated by analyzing convergent validity, discriminant validity, and reliability. Convergent validity was assessed through confirmatory factor analysis (CFA) (O'Leary-Kelly \& Vokurka, 1998). Our proposed structure of environmental and social practices and environmental and social performance resulted in a reasonably good fitting model $\left(X^{2} / \mathrm{df}=1.37\right.$, RMSEA $=0.030$, $\mathrm{CFI}=0.995$, and SRMR=0.017). Furthermore, results in Table 3 show that all factor loadings exceeded the suggested threshold of 0.5 (Vickery, Jayaram, Dröge, \& Calantone, 2003). All factor loadings also exceeded twice the value of their associated standard error, suggesting good convergent validity. Table 4 provides support regarding discriminant validity since the square root of the AVE of each construct is higher than its correlations (Anderson \& Gerbing, 1988). Lastly, reliability was judged by using Cronbach's alpha coefficient. Results in Table 3 show that all the scales have a value greater than the threshold value of 0.70 (Nunnally, 1978), indicating that all constructs are reliable. 


\begin{tabular}{|c|c|c|c|c|c|c|}
\hline Construct & Item & Mean & SD & Loading & S.E. & Cronbach's $\alpha$ \\
\hline \multirow{3}{*}{$\begin{array}{c}\text { Environmental } \\
\text { Practices }\end{array}$} & ENV1 & \multirow{3}{*}{3.51} & \multirow{3}{*}{1.001} & 0.643 & 0.032 & \multirow{3}{*}{0.81} \\
\hline & ENV2 & & & 0.875 & 0.017 & \\
\hline & ENV3 & & & 0.866 & 0.017 & \\
\hline \multirow{3}{*}{$\begin{array}{c}\text { Social } \\
\text { Practices }\end{array}$} & SOC1 & \multirow{3}{*}{3.21} & \multirow{3}{*}{1.007} & 0.811 & 0.024 & \multirow{3}{*}{0.76} \\
\hline & SOC2 & & & 0.668 & 0.032 & \\
\hline & SOC3 & & & 0.645 & 0.034 & \\
\hline \multirow{2}{*}{$\begin{array}{l}\text { Environmental } \\
\text { Performance }\end{array}$} & EPF1 & \multirow{2}{*}{3.46} & \multirow{2}{*}{0.73} & 0.758 & 0.041 & \multirow{2}{*}{0.78} \\
\hline & EPF2 & & & 0.836 & 0.041 & \\
\hline \multirow{2}{*}{$\begin{array}{c}\text { Social } \\
\text { Performance }\end{array}$} & SPF1 & \multirow{2}{*}{3.29} & \multirow{2}{*}{0.66} & 0.740 & 0.035 & \multirow{2}{*}{0.77} \\
\hline & SPF2 & & & 0.846 & 0.034 & \\
\hline
\end{tabular}

Table 3: CFA Results, Convergent Validity, and Reliability

\begin{tabular}{|c|c|c|c|c|}
\hline & $(1)$ & (2) & (3) & (4) \\
\hline Env. Practices (1) & $0.802^{1}$ & & & \\
\hline Social Practices (2) & $0.741^{2}$ & 0.712 & & \\
\hline Env. Performance (3) & 0.299 & 0.295 & 0.798 & \\
\hline Social Performance (4) & 0.351 & 0.449 & 0.449 & 0.795 \\
\hline
\end{tabular}

Table 4: Discriminant Validity

${ }^{1} \mathrm{AVE}$ square root (note: all values in the diagonal are the square-root of AVE).

${ }^{2}$ Correlations

Since our data was collected from one single respondent and at one single point in time, we checked if common method variance (CMV) would be a threat to the validity of our results using a priori and a posteriori procedures. A priori, the dependent (performance) and independent (practices) variables were placed in different and separate sections of the questionnaire (Podsakoff, MacKenzie, Lee, $\&$ Podsakoff, 2003), thus contributing to diminishing the effects of consistency artefacts. A posteriori, we used the Harmans single factor method (Podsakoff et al., 2003). The results of this analysis suggest that a single factor model produces a significantly worse model fit compared to our proposed and confirmed fourfactor model $\left(X^{2} / \mathrm{df}=13.97\right.$, RMSEA=0.179, CFI=0.756, and SRMR=0.102), thereby suggesting that CMV is not a threat to the validity of our results. 


\section{DATA ANALYSIS AND RESULTS}

The objective of this study was to analyze whether national culture, operationalized through the four Hofstede dimensions (power distance, individualism-collectivism, masculinity, and uncertainty avoidance), affects the impact of environmental and social practices on environmental and social performance. In other words, our objective was to analyze the moderating role of national culture in the sustainability practices-sustainability performance relationship. The data in the present study are multilevel in nature, with national culture dimensions and GNI at the country level and practices, performance, and size at the plant level. This implies that the data are clustered with plants nested within countries and that variables are at different levels of analysis. Such characteristics suggest, moreover, that multilevel regression analysis would be the most appropriate method for analyzing the data.

Before estimating our models, we standardized our independent and moderating variables. We also checked the correlation measures between constructs. Tables $5 \mathrm{a}$ and $5 \mathrm{~b}$ show the correlation matrix between national culture dimensions, environmental practices, social practices, environmental performance, and social performance. Given that the results suggest that there is a strong correlation between the two types of practices and between the four dimensions of national culture, we checked for the presence of multicollinearity in our data and computed the variance inflation factors (VIFs). Results suggest that multicollinearity is not an issue in our study since all VIFs were below four, which is less than the commonly used threshold of ten. Moreover, following Wiengarten et al. (2011), we also tested the regression analysis that included the interaction terms in separate models. This allowed us to ensure even further that multicollinearity is not an issue in our analysis.

The results of the multilevel regression analyses are shown in Tables 6 and 7 . A series of models were run for each dependent variable (environmental and social performance). The first was an empty model, which decomposed the variance of the dependent variable into within-group (plant level) variance $\sigma^{2}$ and between group (country level) variance $\tau^{2}{ }_{0}$. Next, we included our control variables (Model 0 ), namely, firm size and GNI. Model 1 then included the direct effects of environmental/ social practices on environmental/social performance. Lastly, we ran four models (Models 2.a, b, c, and d) in which the national culture moderating variable (power distance, individualism-collectivism, masculinity, and uncertainty avoidance) and the interaction effect between it and practices were introduced. 


\begin{tabular}{|c|c|c|c|c|c|c|c|}
\hline & Mean & SD & (1) & (2) & (3) & (4) & (5) \\
\hline $\begin{array}{c}\text { Internal Environmental } \\
\text { Practices (1) }\end{array}$ & 3.513 & 1.001 & 1 & & & & \\
\hline $\begin{array}{c}\text { Internal Social Practices } \\
(2)\end{array}$ & 3.213 & 1.007 & 0.741 & 1 & & & \\
\hline $\begin{array}{c}\text { Environmental } \\
\text { Performance (3) }\end{array}$ & 3.287 & 0.655 & 0.300 & 0.296 & 1 & & \\
\hline Social Performance (4) & 3.463 & 0.726 & 0.351 & 0.450 & 0.449 & 1 & \\
\hline PDI (5) & 63.68 & 17.66 & 0.119 & 0.295 & 0.102 & 0.208 & 1 \\
\hline IDV (6) & 65.87 & 23.49 & -0.144 & -0.190 & -0.007 & -0.148 & -0.122 \\
\hline MAS (7) & 56.20 & 25.72 & -0.162 & -0.293 & -0.140 & -0.269 & -0.593 \\
\hline UAI (8) & 47.54 & 21.97 & -0.031 & -0.195 & -0.033 & -0.094 & -0.804 \\
\hline Size (9) & 6.13 & 1.673 & 0.329 & 0.274 & 0.097 & 0.047 & -0.012 \\
\hline GNI (10) & 22814.52 & 13890.33 & -0.197 & -0.335 & -0.192 & -0.293 & -0.809 \\
\hline
\end{tabular}

\begin{tabular}{|c|c|c|c|c|c|c|c|}
\hline & Mean & SD & (6) & (7) & (8) & (9) & (10) \\
\hline $\begin{array}{c}\text { Internal Environmental } \\
\text { Practices (1) }\end{array}$ & 3.513 & 1.001 & & & & & \\
\hline $\begin{array}{c}\text { Internal Social Practices } \\
(2)\end{array}$ & 3.213 & 1.007 & & & & & \\
\hline $\begin{array}{c}\text { Environmental } \\
\text { Performance (3) }\end{array}$ & 3.287 & 0.655 & & & & & \\
\hline Social Performance (4) & 3.463 & 0.726 & & & & & \\
\hline PDI (5) & 63.68 & 17.66 & & & & & \\
\hline IDV (6) & 65.87 & 23.49 & 1 & & & & \\
\hline MAS (7) & 56.20 & 25.72 & 0.559 & 1 & & & \\
\hline UAI (8) & 47.54 & 21.97 & 0.089 & 0.488 & 1 & & \\
\hline Size (9) & 6.13 & 1.673 & -0.073 & -0.120 & -0.076 & 1 & \\
\hline GNI (10) & 22814.52 & 13890.33 & 0.104 & -0.640 & 0.463 & 0.057 & 1 \\
\hline
\end{tabular}

Tables 5a \& 5b: Correlation Matrix 


\begin{tabular}{|c|c|c|c|c|c|c|c|}
\hline \multicolumn{8}{|c|}{ Dependent Variable: ENVIRONMENTAL PERFORMANCE } \\
\hline Parameters & $\begin{array}{l}\text { Empty } \\
\text { Model }\end{array}$ & $\begin{array}{c}\text { Model } \\
0\end{array}$ & $\begin{array}{c}\text { Model } \\
1\end{array}$ & $\begin{array}{c}\text { Model } \\
\text { 2.a.PDI }\end{array}$ & $\begin{array}{l}\text { Model } \\
\text { 2.b. IDV }\end{array}$ & $\begin{array}{c}\text { Model } \\
\text { 2.c. MAS }\end{array}$ & $\begin{array}{l}\text { Model } \\
\text { 2.d. UAI }\end{array}$ \\
\hline \multicolumn{8}{|c|}{ Grand intercept } \\
\hline Cons & $3.24^{\star \star \star}$ & $3.29^{\star * *}$ & $3.29^{* * *}$ & $3.29 * * *$ & $3.29^{* * *}$ & $3.29 * * *$ & $3.29^{\star * *}$ \\
\hline \multicolumn{8}{|c|}{ Control variables } \\
\hline Firm size & & $0.07^{\star *}$ & 0.01 & 0.01 & 0.01 & 0.01 & 0.02 \\
\hline GNI & & $-0.13^{\star \star \star}$ & $-0.09 * *$ & $-0.16^{\star \star}$ & $-0.09^{* *}$ & $-0.09^{\star *}$ & $-0.11^{\star \star}$ \\
\hline \multicolumn{8}{|c|}{ Independent variables } \\
\hline $\begin{array}{c}\text { Environmental } \\
\text { Practices }\end{array}$ & & & $0.17^{* * *}$ & $0.17^{\star * *}$ & $0.17^{* * *}$ & $0.17^{* * *}$ & $0.17^{* * *}$ \\
\hline $\begin{array}{l}\text { National } \\
\text { Culture } \\
\text { Moderator }\end{array}$ & & & & -0.085 & 0.032 & -0.005 & 0.037 \\
\hline $\begin{array}{l}\text { Nat. Cult } \\
\text { X Env. } \\
\text { Practices }\end{array}$ & & & & 0.002 & 0.026 & 0.000023 & 0.002 \\
\hline$\sigma^{2}$ & 0.413 & 0.409 & 0.383 & 0.381 & 0.381 & 0.383 & 0.382 \\
\hline$\tau_{0}^{2}$ & 0.018 & $1.21 \mathrm{e}^{-21}$ & $1.30 \mathrm{e}^{-23}$ & $8.78 \mathrm{e}^{-18}$ & $1.20 \mathrm{e}^{-24}$ & $2.78 \mathrm{e}^{-24}$ & $1.54 \mathrm{e}^{-24}$ \\
\hline Deviance (D) & 841.15 & 828.32 & 800.56 & 797.92 & 798.87 & 800.55 & 799.49 \\
\hline$A I C$ & 847.15 & 838.32 & 812.56 & 813.92 & 814.87 & 816.55 & 815.49 \\
\hline$B I C$ & 859.31 & 858.60 & 836.89 & 846.36 & 847.31 & 848.99 & 847.92 \\
\hline
\end{tabular}

Table 6: Multilevel Regression Results: Environmental Performance ${ }^{\star} \mathrm{p} \leq 0.10 ;{ }^{* \star} \mathrm{p} \leq 0.05 ;{ }^{* \star \star} \mathrm{p} \leq 0.00$ 


\begin{tabular}{|c|c|c|c|c|c|c|c|}
\hline \multicolumn{8}{|c|}{ Dependent Variable: SOCIAL PERFORMANCE } \\
\hline Parameters & $\begin{array}{l}\text { Empty } \\
\text { Model }\end{array}$ & $\begin{array}{c}\text { Model } \\
0\end{array}$ & $\begin{array}{c}\text { Model } \\
1\end{array}$ & $\begin{array}{l}\text { Model } \\
\text { 2.a.PDI }\end{array}$ & $\begin{array}{l}\text { Model } \\
\text { 2.b. IDV }\end{array}$ & $\begin{array}{c}\text { Model } \\
\text { 2.c. MAS }\end{array}$ & $\begin{array}{l}\text { Model } \\
\text { 2.d. UAI }\end{array}$ \\
\hline \multicolumn{8}{|c|}{ Grand intercept } \\
\hline Cons & $3.42^{* * *}$ & $3.47^{* * *}$ & $3.47^{* * *}$ & $3.49^{\star \star \star}$ & $3.48^{* * *}$ & $3.49^{* * *}$ & $3.49^{* * *}$ \\
\hline \multicolumn{8}{|c|}{ Control variables } \\
\hline Firm size & & 0.04 & -0.04 & -0.04 & -0.05 & -0.05 & -0.03 \\
\hline GNI & & $-0.19^{\star * *}$ & $-0.11^{\star * *}$ & $-0.18^{\star * *}$ & $-0.11^{* * *}$ & $-0.08^{*}$ & $-0.13^{\star * *}$ \\
\hline \multicolumn{8}{|c|}{ Independent variables } \\
\hline Social Practices & & & $0.30^{\star \star \star}$ & $0.30^{\star * *}$ & $0.28^{* * *}$ & $0.29^{\star * *}$ & $0.30^{* * *}$ \\
\hline $\begin{array}{l}\text { National } \\
\text { Culture } \\
\text { Moderator }\end{array}$ & & & & $-0.097^{\star}$ & -0.03 & -0.053 & $0.067^{*}$ \\
\hline $\begin{array}{c}\text { Nat. Cult X } \\
\text { Soc.Practices }\end{array}$ & & & & -0.048 & $0.06^{*}$ & $0.078^{\star *}$ & $0.081^{* *}$ \\
\hline$\sigma^{2}$ & 0.457 & 0.457 & 0.392 & 0.387 & 0.387 & 0.383 & 0.384 \\
\hline$\tau_{0}^{2}$ & 0.037 & 0.005 & $1.94 \mathrm{e}^{-20}$ & $5.34 \mathrm{e}^{-18}$ & $3.76 \mathrm{e}^{-18}$ & $9.65 \mathrm{e}^{-17}$ & $2.54 \mathrm{e}^{-17}$ \\
\hline Deviance $(D)$ & 888.15 & 879.15 & 809.73 & 805.57 & 804.69 & 800.24 & 801.58 \\
\hline$A I C$ & 894.15 & 889.15 & 821.73 & 821.57 & 820.69 & 816.24 & 817.58 \\
\hline$B I C$ & 906.31 & 909.42 & 846.05 & 854.00 & 853.12 & 838.68 & 840.02 \\
\hline
\end{tabular}

Table 7: Multilevel Regression Results: Social Performance ${ }^{*} \mathrm{p} \leq 0.10 ;{ }^{* \star} \mathrm{p} \leq 0.05 ;{ }^{* *} \mathrm{p} \leq 0.00$

\section{Environmental Practices and Performance}

The ICC at the country level for environmental performance is $4 \%$, which means that $4 \%$ of the unexplained variance of environmental performance is between countries. Model 0 shows that both firm size and GNI are significant, with a firm's size positively associated with environmental performance while GNI is negatively associated. From these two control variables, however, only GNI remains negative and significant across models. Model 1 shows that environmental practices are positively and significantly associated with environmental performance $(\beta=0.17$, $\mathrm{p}<0.001$ ). None of the moderating models (Models 2.a, b, c, and d) show significant results for the moderating role of national culture on the positive and significant relationship between environmental practices and environmental performance. The assessment of model fit also highlights the absence of moderation effects and indicates that the best model is Model 1 since it has the lowest values for Deviance, $\mathrm{AIC}$, and BIC. These results do not provide support for $\mathrm{H} 1 \mathrm{a}, \mathrm{H} 2 \mathrm{a}, \mathrm{H} 3 \mathrm{a}$, and $\mathrm{H} 4 \mathrm{a}$, 
which hypothesized a moderating role of national culture in the environmental practices-performance relationship.

\section{Social Practices and Performance}

The ICC at the country level for social performance is around $8 \%$, which means that $8 \%$ of the unexplained variance of social performance is between countries. Model 0 shows that GNI is negatively and significantly related to social performance. Model 1 indicates that social practices are positively and significantly associated with social performance $(\beta=0.30, \mathrm{p}<0.001)$. Models 2.c and 2.d show that masculinity $(\beta=0.78$, $\mathrm{p}<0.005)$ and uncertainty avoidance $(\beta=0.081, \mathrm{p}<0.005)$ positively moderate the positive relationship between social practices and social performance. Model fit indicators show that the deviance for moderating models (Models 2.a, b, c, and d) is lower than that of the direct effects model (Model 1). However, given that deviance is always reduced by the inclusion of additional predictors, it is necessary to check AIC and BIC indicators. The lowest AIC and BIC values as such correspond to Models 2.c and 2.d.

\begin{tabular}{|c|c|c|}
\hline HYPOTHESIS & $\begin{array}{c}\text { ENVIRONMENTAL } \\
\text { MODEL }\end{array}$ & $\begin{array}{l}\text { SOCIAL } \\
\text { MODEL }\end{array}$ \\
\hline $\begin{array}{l}\text { H1: Power distance } \\
\text { weakens the relationship } \\
\text { between practices and } \\
\text { performance }\end{array}$ & $\begin{array}{c}\text { No effect } \\
\text { NO SUPPORT FOR } \\
\text { H1a }\end{array}$ & $\begin{array}{c}\text { No effect } \\
\text { NO SUPPORT FOR } \\
\text { H1b }\end{array}$ \\
\hline $\begin{array}{l}\text { H2: Individualism } \\
\text { weakens the relationship } \\
\text { between practices and } \\
\text { performance }\end{array}$ & $\begin{array}{c}\text { No effect } \\
\text { NO SUPPORT FOR } \\
\text { H2a }\end{array}$ & $\begin{array}{c}\text { No effect } \\
\text { NO SUPPORT FOR } \\
\text { H2b }\end{array}$ \\
\hline $\begin{array}{l}\text { H3: Masculinity } \\
\text { weakens the relationship } \\
\text { between practices and } \\
\text { performance }\end{array}$ & $\begin{array}{c}\text { No effect } \\
\text { NO SUPPORT FOR } \\
\text { H3a }\end{array}$ & $\begin{array}{c}\text { Positive effect (not } \\
\text { in the hypothesized } \\
\text { direction) } \\
\text { NO SUPPORT FOR } \\
\text { H3b }\end{array}$ \\
\hline $\begin{array}{l}\text { H4: Uncertainty } \\
\text { avoidance strengthens } \\
\text { the relationship } \\
\text { between practices and } \\
\text { performance }\end{array}$ & $\begin{array}{c}\text { No effect } \\
\text { NO SUPPORT FOR } \\
\text { H4a }\end{array}$ & $\begin{array}{c}\text { Positive effect } \\
\text { SUPPORT FOR H4b }\end{array}$ \\
\hline
\end{tabular}

Table 8: Hypotheses Testing 
Overall, these results provide support for $\mathrm{H} 4 \mathrm{~b}$, which posited that uncertainty avoidance strengthens the relationship between social practices and social performance. Our results also found a significant moderating effect of masculinity on the social practices-social performance relationship, although not in the direction hypothesized. Table 8 summarizes the results of hypotheses testing.

\section{DISCUSSION}

Our results in general contribute to the stream of literature that is at the crossroads of sustainability and national culture (e.g., Ringov \& Zollo, 2007; Caprar \& Neville, 2012; Thanetsunthorn, 2015). Previous literature show that national culture plays a role in the organizational decision to implement sustainability practices. Our study adds to this research by showing not only that national culture influences the adoption of sustainability practices, as is also indicated by previous research, but that some of its dimensions also moderate the relationship between sustainability practices and sustainability performance. This means that while certain national cultural environments favor or deter the adoption of sustainability practices, the results of such implementations of sustainability practices can also vary according to different national cultural traits.

Regarding the specific dimensions of national culture, our results have found support for the moderating effect of the uncertainty avoidance and masculinity dimensions but only for the social dimension of sustainability. In other words, countries that score high in uncertainty avoidance and masculinity will have higher social performance as a result of the implementation of sustainability practices.

We now examine the specific results for each dimension, with the remainder of the discussion structured as follows: first, we comment on our results by comparing the environmental and social models and providing possible explanations for the existence of the moderating role of national culture only in the social model, and second, we provide some explanations for the moderating role of the different national culture dimensions. 


\section{Environmental Model vs. Social Model}

While our results show some limited support for a moderating role of national culture in the social model, we have yet to find support for the moderating role of national culture in the environmental model. This result can be explained by the fact that environmental practices are more related to products and technologies than to human resources, which are influenced by the external environment in which they are embedded. For example, programs aimed at reducing energy and water consumption in a manufacturing context may be more related with the technology used than with the actions of employees. Programs to reduce pollution emission, in similar fashion, will be more likely related with technology than with the actions of human resources. On the other hand, the impact of social programs such as health and safety actions and the implementation of work/life balance policies on performance depends more on the beliefs and attitudes of individuals than on technology. National culture influences employees' understanding of work and their approach to it (Newman \& Nollen, 1996), making it reasonable to infer that it influences mainly the impact of social practices on performance.

\section{The Social Model: The Moderating Role of Different National Culture Dimensions}

Our results also show, contrary to what we hypothesized, that the dimensions of power distance and individualism-collectivism have no moderating effect. This means that the impact of sustainability practices on sustainability performance is the same regardless of the levels of power distance and individualism. Indeed, while Ringov and Zollo (2007) found that recognition and remedy of social and environmental risks are timely addressed in contexts characterized by low power distance scores, our results show that this context does not affect the effectiveness of sustainability practices. Despite the fact that individuals in high power distance societies are less sensitive toward ethical acts and more tolerant of inequality (House et al., 2004; Scholtens \& Dam, 2007), this cultural trait does not affect the effectiveness of health, safety, and work/life balance practices. Based on these results, we can thus conclude that while the power distance dimension acts as a context variable leading to the implementation of sustainability practices, it does not affect the effectiveness of their implementation.

We hypothesized that individualism would moderate the relationship between social practices and social performance given that individuals in societies with high 
individualism believe that their personal interests are more important than those of others and demonstrate less concern about the impact of business on society and the environment (Thanetsunthorn, 2015). Our results show, however, that the effectiveness of work/life balance and health and safety practices is the same regardless of the individualistic trait of the society in which they are implemented.

Regarding the role of uncertainty avoidance, our results provide support, in line with Thanetsunthorn (2015) and Wagner (2009), for the hypothesized positive moderating effect. Our findings suggest that the adoption of social practices will fit well and hence exhibit higher levels of performance in organizations located in high uncertainty avoidance societies compared to those in low uncertainty avoidance contexts. The fact that high uncertainty avoidance societies value the existence of norms and codes of conduct that avoid risky behaviors helps them better grasp the benefits of implementing social practices. The interaction plot in Figure 2, which depicts the two-way interaction of social practices and uncertainty avoidance on social performance, shows that social practices have a stronger positive impact on a firm's social performance in contexts of high uncertainty avoidance.

Although we found a significant interaction from the masculinity/femininity national culture dimension, its direction is not as was expected. Based on the fact that an environment characterized by high femininity levels would favor the implementation of sustainable practices (Katz et al., 2001; Husted, 2005), we hypothesized that masculinity would weaken the relationship between sustainable practices and sustainable performance due to a lack of fit between masculinity traits and sustainability practices. Our results show, however, that the higher the level of masculinity, the higher the effect of sustainability practices.

To explain such an interaction effect, the slopes of the regression of social practices on social performance at low (one SD below the mean) and high (one SD above the mean) levels of masculinity are shown in Figure 3. As it can be appreciated, the slopes of this figure are different from those of Figure 2. The social performance of firms located in low masculinity countries, which are characterized by a preference for cooperation, modesty, caring for the weak, and quality of life, is lower than that of firms located in high masculinity countries and with the same level of implementation of social practices. As such, while previous research found that a masculinity context does not favor the adoption of sustainability practices (e.g., Thanetsunthorn, 2015; Katz et al., 2001), future research might want 
to consider additional moderating variables that might counterbalance this effect (e.g., organizational culture).

In summary, whereas the dimensions of power distance and individualismcollectivism have no moderating effect, the dimensions of masculinity and uncertainty avoidance have a moderating role but with different effects. In societies characterized by high levels of masculinity, the implementation of social practices counterbalances their generally low level of care for the weak and for the quality of life. A high level of uncertainty avoidance, on the other hand, facilitates the implementation of these practices and strengthens their impact.

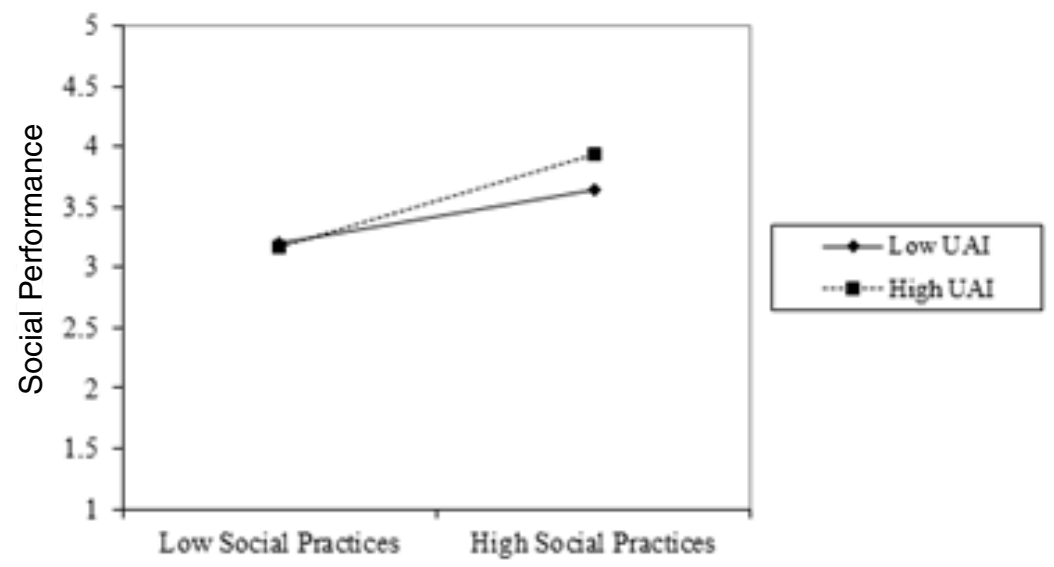

Figure 2: Interaction Slopes for Social Practices and Social Performance and UAI

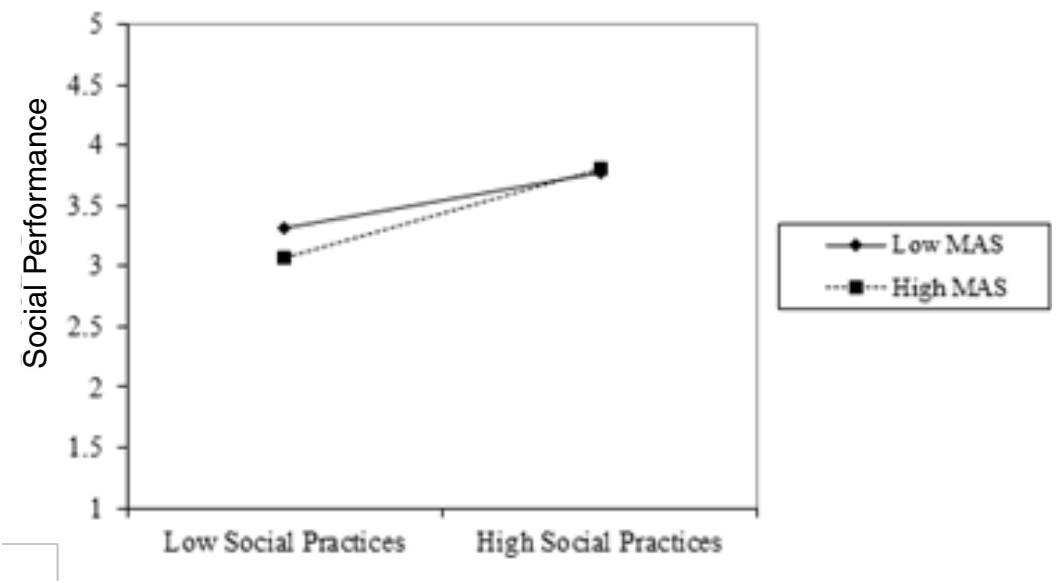

Figure 3: Interaction Slopes for Social Practices and Social Performance and MAS 


\section{CONCLUSIONS}

In this paper, we showed the contingent role of national culture on the sustainability practices-sustainability performance relationship. More specifically, our results indicate that both the uncertainty avoidance and masculinity dimensions are relevant contingency variables that should be considered when analyzing the aforementioned relationship. Regarding uncertainty avoidance, our results show that the impact from implementing sustainability practices will be more significant in societies where individuals are willing to put in place systems and procedures to ensure the sustainability of the society and the environment (by reducing or removing any uncertainty that might have a negative impact on them). In the case of the masculinity-femininity dimension, our results indicate that the implementation of social practices results in higher performance results in societies characterized by high levels of masculinity than in countries scoring low on masculinity.

Our findings are interesting for both researchers and managers. Previous literature had focused on managerial perceptions, the decision-making processes of managers, or the direct impact of national culture on sustainability performance. Our paper as such contributes to the sustainability literature by showing the moderating effect of some aspects of national culture on the sustainability practices-performance relationship and that culture needs to be considered as a contingent variable given that some cultural environments can enhance the impact of sustainability practices.

The following managerial implications have been derived as a result of our study. First, managers of global firms need to distinguish between environmental and social practices; more specifically, they should pay special attention to the role that national culture plays in the effectiveness of social practices. Second, managers of multinational firms can understand better why the impact of their social practices on performance is not uniform. They can expect the implementation of social practices such as SA8000, OHSAS 18000, formal occupational health and safety management systems, and work/life balance policies to have a higher impact on workers' motivation as well as on health and safety conditions in countries with high uncertainty avoidance and/or high masculinity levels. Third, there will be less need for the implementation of social practices in countries with low masculinity scores as this national culture trait already favors the motivation of workers as well as improved health and safety conditions. In the case, therefore, of firms with subsidiaries or plants located in different regions across the globe, these aspects 
highlight the need for managers to adapt and define their sustainability action plans in consideration of possible national cultural differences.

Besides these contributions, however, our paper has some limitations that need to be acknowledged. First, we used the perceptions of managers regarding their environmental and social performance with respect to their major competitors. Although we are not interested in the direct effect of practices on performance, using perceptual measures is a limitation nevertheless. Further research, therefore, should consider objective data for these performance measures. Second, additional control variables at the firm level, such as R\&D expenditure or corporate governance policies, might also be included as they can play a role in achieving better sustainability performance outcomes. Third, we considered the moderating role of national culture. Further research, however, should consider if an organizational culture that fits the sustainability values can counterbalance the possible negative effect of a specific trait of the national culture.

We also used survey methodology which is excellent for identifying contingency effects but does not provide explanations for the observed effects. Future studies should therefore develop case research to understand the moderating role of national culture better. Also, while we have been able to ensure high internal validity by choosing and limiting our study to the manufacturing setting, we are aware that results may differ in other settings (i.e., the service sector). Both the environmental and social models may behave in a similar way, for example, in industries or sectors that are less capital intensive. In terms of generalizability, therefore, it would be useful for further research to explore if our findings also hold for other industries and sectors. Lastly, while different national cultures were included in our study, the sample of countries was limited to European and Asian regions. Further research should expand the sample to include countries in other regions such as America and/or Africa, thereby including more variation in national culture environments. 


\begin{tabular}{|c|c|c|}
\hline CONSTRUCT & $\begin{array}{c}\text { ITEM (scale of } 1 \text { to } 5 \text {, where } 1 \text { indicates none and } \\
5 \text { indicates a high level of implementation) }\end{array}$ & REFERENCES \\
\hline \multirow{3}{*}{$\begin{array}{l}\text { Environmental } \\
\text { Practices }\end{array}$} & $\begin{array}{l}\text { ENV1. Environmental certifications } \\
\text { (e.g., EMAS or ISO 14001) }\end{array}$ & \multirow{3}{*}{$\begin{array}{l}\text { Adapted from } \\
\text { Klassen and } \\
\text { Whybark } \\
\text { (1999) and } \\
\text { Sarkis (1998) }\end{array}$} \\
\hline & $\begin{array}{l}\text { ENV2. Energy and water consumption } \\
\text { reduction programs }\end{array}$ & \\
\hline & $\begin{array}{l}\text { ENV3. Pollution emission reduction and } \\
\text { waste recycling programs }\end{array}$ & \\
\hline \multirow{3}{*}{$\begin{array}{l}\text { Social } \\
\text { Practices }\end{array}$} & $\begin{array}{l}\text { SOC1. Social certifications } \\
\text { (e.g., SA8000 or OHSAS 18000) }\end{array}$ & \multirow{3}{*}{$\begin{array}{l}\text { Adapted from } \\
\text { Longo et al. } \\
\quad(2005)\end{array}$} \\
\hline & $\begin{array}{l}\text { SOC2. Formal occupational health and safety } \\
\text { management system }\end{array}$ & \\
\hline & SOC3. Work/life balance policies & \\
\hline
\end{tabular}

\begin{tabular}{|c|c|c|}
\hline CONSTRUCT & $\begin{array}{c}\text { ITEM (scale of } 1 \text { to } 5 \text {, where } 1 \text { indicates much } \\
\text { worse than, } 3 \text { equal to, and } 5 \text { much better than } \\
\text { main competitor) }\end{array}$ & REFERENCES \\
\hline \multirow{2}{*}{$\begin{array}{c}\text { Environmental } \\
\text { Performance }\end{array}$} & $\begin{array}{c}\text { EPF1. Materials, water, and/or } \\
\text { energy consumption }\end{array}$ & $\begin{array}{c}\text { Zhu and } \\
\text { Sarkis (2004) }\end{array}$ \\
\cline { 2 - 2 } $\begin{array}{c}\text { Social } \\
\text { Performance }\end{array}$ & $\begin{array}{c}\text { EPF2. Pollution emission and waste } \\
\text { production levels }\end{array}$ & $\begin{array}{c}\text { Gimenez et al. } \\
\text { (2012) }\end{array}$ \\
\cline { 2 - 3 } & SPF2. Health and safety conditions \\
\hline
\end{tabular}

Appendix A: List of Items, Description, and Source

\section{REFERENCES}

Anderson, J. C., \& Gerbing, D. W. 1988. Structural equation modelling in practice: A review and recommended two-step approach. Psychological Bulletin, 103(3): 411-423.

Arellano, M. C., Sancha, C., Netland, T., \& Thomsen, C. G. 2020. Manufacturing network integration and culture: An institution-based view. Journal of Manufacturing Technology Management, vol. and no. ahead-of-print.

Cagliano, R., Caniato, F., Golini, R., Longoni, A., \& Micelotta, E. 2011. The impact of country culture on the adoption of new forms of work organization.

International Journal of Operations \& Production Management, 31(3): 297-323. 
Caprar, D. V., \& Neville, B. A. 2012. "Norming" and "conforming": Integrating cultural and institutional explanations for sustainability adoption in business. Journal of Business Ethics, 110(2): 231-245.

Cohen, J. R., Pant, L. W., \& Sharp, D. J. 1996. A methodological note on crosscultural accounting ethics research. The International Journal of Accounting, 31(1): 55-66.

Drazin, R., \& van de Ven, A. H. 1985. Alternative forms of fit in contingency theory. Administrative Science Quarterly, 30(4): 514-539.

Elkington, J. 1994. Towards the sustainable corporation: Win-win-win business strategies for sustainable development. California Management Review, 36(2): 90-100.

Gimenez, C., Sierra, V., \& Rodon, J. 2012. Sustainable operations: Their impact on the triple bottom line. International Journal of Production Economics, 140(1): 149-159.

Golini, R., de Marchi, V., Boffelli, A., \& Kalchschmidt, M. 2018. Which governance structures drive economic, environmental, and social upgrading? A quantitative analysis in the assembly industries. International Journal of Production Economics, 203: 13-23.

Golini, R., Longoni, A., \& Cagliano, R. 2014. Developing sustainability in global manufacturing networks: The role of site competence on sustainability performance. International Journal of Production Economics, 147: 448-459.

Gray, J. V., \& Massimino, B. 2014. The effect of language differences and national culture on operational process compliance. Production and Operations Management, 23(6): 1042-1056.

Hofstede, G. 1980. Culture's consequences: International differences in workrelated values. Newbury Park, CA: Sage.

Hofstede, G. 1983. The cultural relativity of organizational practices and theories. Journal of International Business Studies, 14(2): 75-89. 
Hofstede, G. 1985. The interaction between national and organizational value systems. Journal of Management Studies, 22(4): 347-357.

Hofstede, G. 2001. Culture's consequences: Comparing values, behaviors, institutions, and organizations across nations. Thousand Oaks, CA: Sage Publications, Inc.

House, R. J., Hanges, P. J., Javidan, M., Dorfman, P., \& Gupta, V. (Eds.). 2004. Culture, leadership, and organizations: The GLOBE study of 62 societies. Thousand Oaks, CA: Sage Publications.

Husted, B. W. 2005. Culture and ecology: A cross-national study of the determinants of environmental sustainability. Management International Review, 45(3): 349-371.

IMSS. 2013. International Manufacturing Strategy Survey, sixth iteration. Available through http://www.manufacturingstrategy.net/.

Katz, J. P., Swanson, D. L., \& Nelson, L. K. 2001. Culture-based expectations of corporate citizenship: A propositional framework and comparison of four cultures. The International Journal of Organizational Analysis, 9(2): 149-171.

Klassen, R. D., \& Whybark, D. C. 1999. The impact of environmental technologies on manufacturing performance. Academy of Management Journal, 42(6): 599-615.

Kroeber, A. L., \& Kluckhohn, C. 1952. Culture: A critical review of concepts and definitions. Cambridge, MA: Peabody Museum of American Archaeology and Ethnology.

Lawrence, P. R., \& Lorsch, J. W. 1967. Differentiation and integration in complex organizations. Administrative Science Quarterly, 12(1): 1-47.

Longo, M., Mura, M., \& Bonoli, A. 2005. Corporate social responsibility and corporate performance: The case of Italian SMEs. Corporate Governance, 5(4): 28-42.

Luo, L., Tang, Q., \& Peng, J. 2018. The direct and moderating effects of power distance on carbon transparency: An international investigation of cultural value 
and corporate social responsibility. Business Strategy and the Environment, 27(8): 1546-1557.

Magnusson, P., Wilson, R. T., Zdravkovic, S., Zhou, J. X., \& Westjohn, S. A. 2008. Breaking through the cultural clutter: A comparative assessment of multiple cultural and institutional frameworks. International Marketing Review, 25(2): 183-201.

Matei, M. C., \& Abrudan, M. M. 2018. Are national cultures changing? Evidence from the World Values Survey. Procedia-Social and Behavioral Sciences, 238: 657-664.

Merritt, A. 2000. Culture in the cockpit: Do Hofstede's dimensions replicate? Journal of Cross-Cultural Psychology, 31(3): 283-301.

Min, H., \& Galle, W. P. 2001. Electronic commerce-based purchasing: A survey on the perceptual differences between large and small organisations. International Journal of Logistics Research and Applications, 4(1): 79-95.

Moorman, R. H., \& Blakely, G. L. 1995. Individualism-collectivism as an individual difference predictor of organizational citizenship behavior. Journal of Organizational Behavior, 16(2): 127-142.

Newman, K. L., \& Nollen, S. D. 1996. Culture and congruence: The fit between management practices and national culture. Journal of International Business Studies, 27(4): 753-779.

Nunnally, J. C. 1978. Psychometric theory. New York, NY: McGraw-Hill.

O'Leary-Kelly, S. W., \& Vokurka, R. J. 1998. The empirical assessment of construct validity. Journal of Operations Management, 16(4): 387-405.

Pagell, M., Katz, J. P., \& Sheu, C. 2005. The importance of national culture in operations management research. International Journal of Operations \& Production Management, 25(4): 371-394.

Parboteeah, K. P., Addae, H. M., \& Cullen, J. B. 2012. Propensity to support sustainability initiatives: A cross-national model. Journal of Business Ethics, 105(3): 403-413. 
Park, N. K., Mezias, J. M., \& Song, J. 2004. A resource-based view of strategic alliances and firm value in the electronic marketplace. Journal of Management, 30(1): 7-27.

Peng, Y. S., \& Lin, S. S. 2009. National culture, economic development, population growth and environmental performance: The mediating role of education. Journal of Business Ethics, 90(2): 203-219.

Podsakoff, P. M., MacKenzie, S. B., Lee, J.-Y., \& Podsakoff, N. P. 2003. Common method biases in behavioral research: A critical review of the literature and recommended remedies. Journal of Applied Psychology, 88(5): 879-903.

Power, D., Schoenherr, T., \& Samson, D. 2010. The cultural characteristic of individualism/collectivism: A comparative study of implications for investment in operations between emerging Asian and industrialized Western countries. Journal of Operations Management, 28(3): 206-222.

Ringov, D., \& Zollo, M. 2007. The impact of national culture on corporate social performance. Corporate Governance, 7(4): 476-485.

Sarkis, J. 1998. Evaluating environmentally conscious business practices. European Journal of Operational Research, 107(1): 159-174.

Scholtens, B., \& Dam, L. 2007. Cultural values and international differences in business ethics. Journal of Business Ethics, 75(3): 273-284.

Seuring, S., \& Müller, M. 2008. From a literature review to a conceptual framework for sustainable supply chain management. Journal of Cleaner Production, 16(15): 1699-1710.

Singh, J. 1995. Measurement issues in cross-national research. Journal of International Business Studies, 26(3): 597-620.

Sivakumar, K., \& Nakata, C. 2001. The stampede toward Hofstede's framework: Avoiding the sample design pit in cross-cultural research. Journal of International Business Studies, 32(3): 555-574.

Smith, P. B. 1992. Organizational behaviour and national cultures. British Journal of Management, 3(1): 39-51. 
Thanetsunthorn, N. 2015. The impact of national culture on corporate social responsibility: Evidence from cross-regional comparison. Asian Journal of Business Ethics, 4(1): 35-56.

Thompson, J. D. 1967. Organizations in action. New York: McGraw-Hill.

Tice, D. M., \& Baumeister, R. F. 1985. Masculinity inhibits helping in emergencies: Personality does predict the bystander effect. Journal of Personality and Social Psychology, 49(2): 420-428.

Triandis, H. C. 1995. Individualism \& collectivism. Boulder, CO: Westview Press.

Vachon, S. 2010. International operations and sustainable development: Should national culture matter? Sustainable Development, 18(6): 350-361.

Vecchi, A., \& Brennan, L. 2009. Quality management: A cross-cultural perspective. Cross Cultural Management: An International Journal, 16(2): 149-164.

Vickery, S. K., Jayaram, J., Dröge, C., \& Calantone, R. 2003. The effects of an integrative supply chain strategy on customer service and financial performance: An analysis of direct versus indirect relationships. Journal of Operations Management, 21(5): 523-539.

Vitell, S. J., \& Festervand, T. A. 1987. Business ethics: Conflicts, practices and beliefs of industrial executives. Journal of Business Ethics, 6(2): 111-122.

Vitell, S. J., Nwachukwu, S. L., \& Barnes, J. H. 1993. The effects of culture on ethical decision-making: An application of Hofstede's typology. Journal of Business Ethics, 12(10): 753-760.

Wagner, M. 2009. National culture, regulation and country interaction effects on the association of environmental management systems with environmentally beneficial innovation. Business Strategy and the Environment, 18(2): 122-136.

Wiengarten, F., Fynes, B., Pagell, M., \& Búrca, S. D. 2011. Exploring the impact of national culture on investments in manufacturing practices and performance: An empirical multi-country study. International Journal of Operations \& Production Management, 31(5): 554-578. 
Wiengarten, F., Pagell, M., Ahmed, M. U., \& Gimenez, C. 2014. Do a country's logistical capabilities moderate the external integration performance relationship? Journal of Operations Management, 32(1-2): 51-63.

Wong, C. W. Y., Sancha, C., \& Thomsen, C. G. 2017. A national culture perspective in the efficacy of supply chain integration practices. International Journal of Production Economics, 193: 554-565.

World Bank. n.d. The World Bank IBRD+IDA data. Available at https://data. worldbank.org/indicator/.

Zhu, Q., \& Sarkis, J. 2004. Relationships between operational practices and performance among early adopters of green supply chain management practices in Chinese manufacturing enterprises. Journal of Operations Management, 22(3): 265-289.

Cristina Sancha is a Lecturer in the Department of Operations, Innovation, and Data Sciences at ESADE. She holds a PhD in Management Sciences as well as a Master of Research, Bachelor, and Master in Business Administration from ESADE Business School, Ramon Llull University, Barcelona. Her research interests are centered around the concepts of sustainable operations and supply chain management; more specifically, she investigates in her main research line the mechanisms that help extend sustainability upstream along the supply chain as well as their antecedents and performance outcomes. Her research has been published in international academic journals and presented at national and international conferences.

Annachiara Longoni is an Associate Professor in the Department of Operations, Innovation, and Data Sciences at ESADE Business School, Ramon Llull University, Barcelona. She holds a PhD in Management, Economics, and Industrial Engineering as well as Master of Science and Bachelors degrees in Management Engineering from Politecnico di Milano, Italy. She previously spent time as a visiting scholar at Schulich School of Business, York University, Canada. Her research explores new manufacturing and supply chain paradigms related to sustainability management and has been published in several relevant academic journals. She collaborates with several 
universities, research centers, and companies, and is part of the organizing committee of the EurOMA Forum on Sustainable Operations and Supply Chains.

Cristina Giménez is a Professor of Operations and Supply Chain Management at ESADE Business School, Ramon Llull University, Barcelona. Her areas of interest are sustainable operations and supply chain integration, on which she has published over 30 articles in specialized journals as well as presented papers at national and international conferences. Her recent papers have been published in Journal of Operations Management, International Journal of Operations and Production Management, International Journal of Production Economics, and Journal of Supply Chain Management. Cristina has been serving as Director of Identity and Mission at ESADE since January 2019 and as Co-Editor in Chief of the International Journal of Operations and Production Management (which had an impact factor of 2,955 in Q1) since October 2017. 